\title{
51. CLAY MINERALS IN BASALTS FROM DEEP SEA DRILLING PROJECT SITES 417 AND 418
}

\author{
V. L. Rusinov, I. P. Laputina, G. N. Muravitskaja, and B. B. Zvjagin, Institute of Geology of Ore Deposits, \\ Petrography, Mineralogy, and Geochemistry (IGEM), Academy of Sciences of the USSR, Moscow \\ and \\ B. P. Gradusov, Institute of Soils, Academy of Sciences of the USSR, Moscow
}

\section{INTRODUCTION}

Clay minerals are common in altered rocks from Holes 417A, 417D, and 418A. Among the clay minerals $^{1}$ investigated in this study are smectites, celadonitic hydromica, mixed-layered silicates of mica-montmorillonite, and palagonite-like material. They are observed in the altered volcanic glass of hyaloclastites (Figure 1) and in basalts, as pseudomorphs after phenocrysts in basalts and as a fill in cracks and vesicles.

Minerals of the montmorillonite group and mixedlayered silicates were observed in nearly all samples investigated, even in samples of weakly altered rocks. Their mode of occurrence and mineral assemblages are described in this paper.

Under microscopic examination, three main types of smectites and mixed-layered silicates are distinguished: (1) colorless and light green (after plagioclase); (2) deep green (after olivine and hyaloclastite glass, rarely after pyroxene), and (3) brown (after basaltic glass). Pink montmorillonite was observed in two thin sections (Samples 417D-42-1, $3 \mathrm{~cm}$ and 417D-43-6, $3 \mathrm{~cm}$ ). Type 1 is composed of fine-grained aggregates (Figure 2) which often form cross-fibrous ribbons, spherolites, and (rarely) long fibers. The mineral has the following characteristics: $\alpha=1.490$ to $1.500, \beta=1.508$ to 1.515 , and $\gamma=$ 1.510 to 1.518 ; it is associated with $\mathrm{K}$-feldspars, calcite, and more rarely with analcime and chalcedony. Type 2 occurs in various forms in the samples: as spherolites, crypto-grained masses, cross-fibrous layered bands alternating with light and dark colored layers (Figure 3), and as fibrous aggregates in pseudomorphs after olivine. Optically, this mineral is close to Type 1 with $\alpha$ $=1.486$ to $1.497, \beta=1.503$ to 1.420 , and $\gamma=1.508$ to 1.525 , but has slight pleochroism $(\mathrm{y}=$ green, $\alpha=$ light green). It is associated with calcite, celadonite, and mixed-layered minerals. In some veins, with dark green smectite, pyrite crystals were observed (i.e., the lower portion of the cored interval in Hole 417A).

Brown and dark olive-green smectites (Type 3) usually form crypto-grained or fine-grained masses after palagonitized glass in basalt. The color is variable: bright brown, dark brown, brown, light brown, and greenish brown; however, pleochroism was not ob-

${ }^{1}$ According to J. R. Cann (personal communication), chloritedelessite in association with $\mathrm{K}_{\mathrm{sp}}$ lined some veinlets in Hole 418A. The chemical composition of the chlorite is as follows (wt. $\%$ ): $\mathrm{SiO}_{2}=36$, $\mathrm{Al}_{2} \mathrm{O}_{3}=11, \mathrm{FeO}=12, \mathrm{MgO}=22, \mathrm{CaO}=0-3$, and $\mathrm{K}_{2} \mathrm{O}=0.5$.

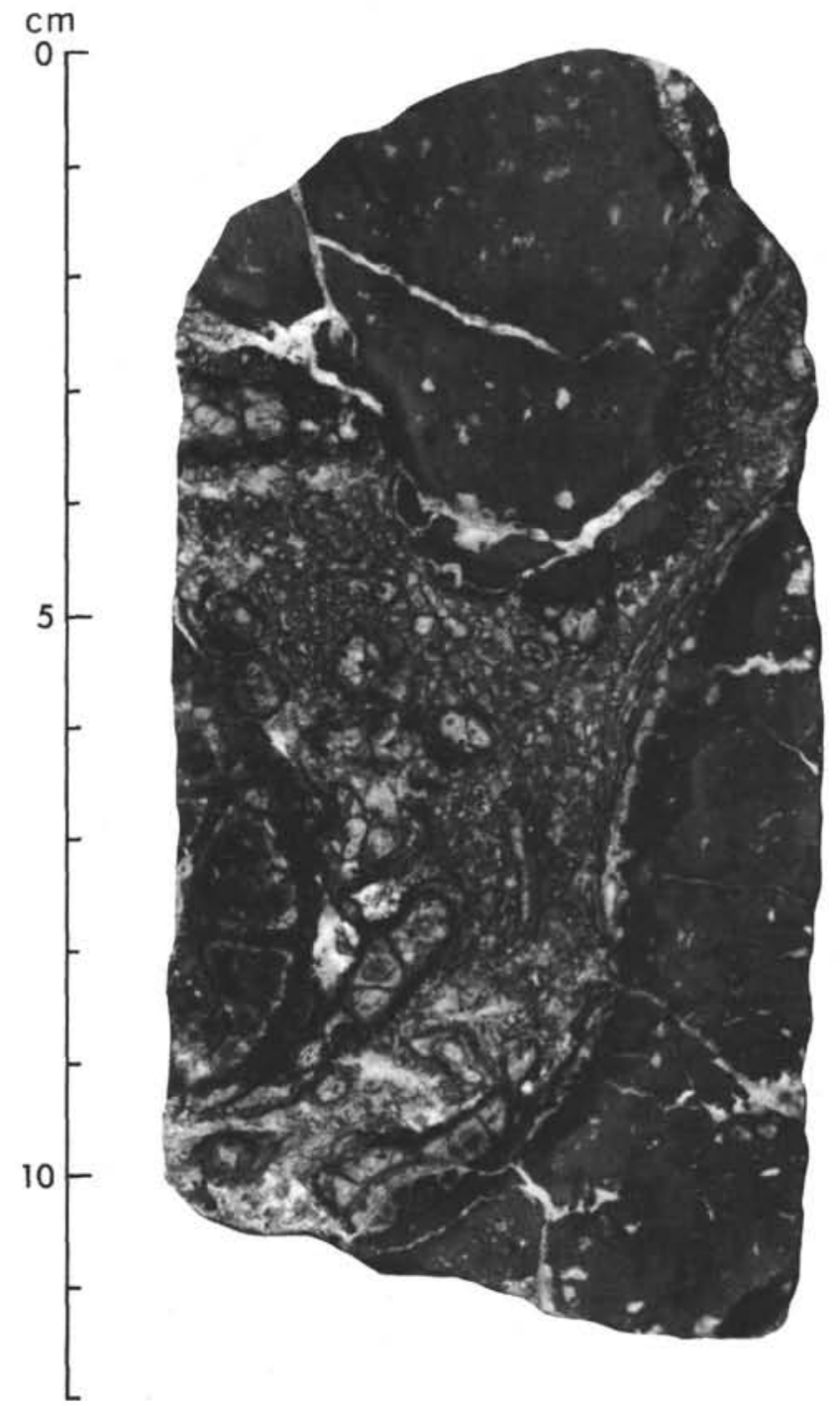

Leg 51A Hole 417A Core 24 Section 2 Sample No. 1

Figure 1. Hyaloclastite with basaltic fragments. The glass is replaced by the mixture of green smectite, calcite, and celadonite.

served. It has higher refractive indexes than either Types 1 and 2 , with $\alpha=1.525$ to $1.540, \mathrm{~B}=1.550$ to $1.560, \gamma=$ 1.556 to 1.566 . It is sometimes associated with celadonite.

Clay minerals were identified optically and with $\mathrm{X}$-ray analysis. Some powder patterns were studied 


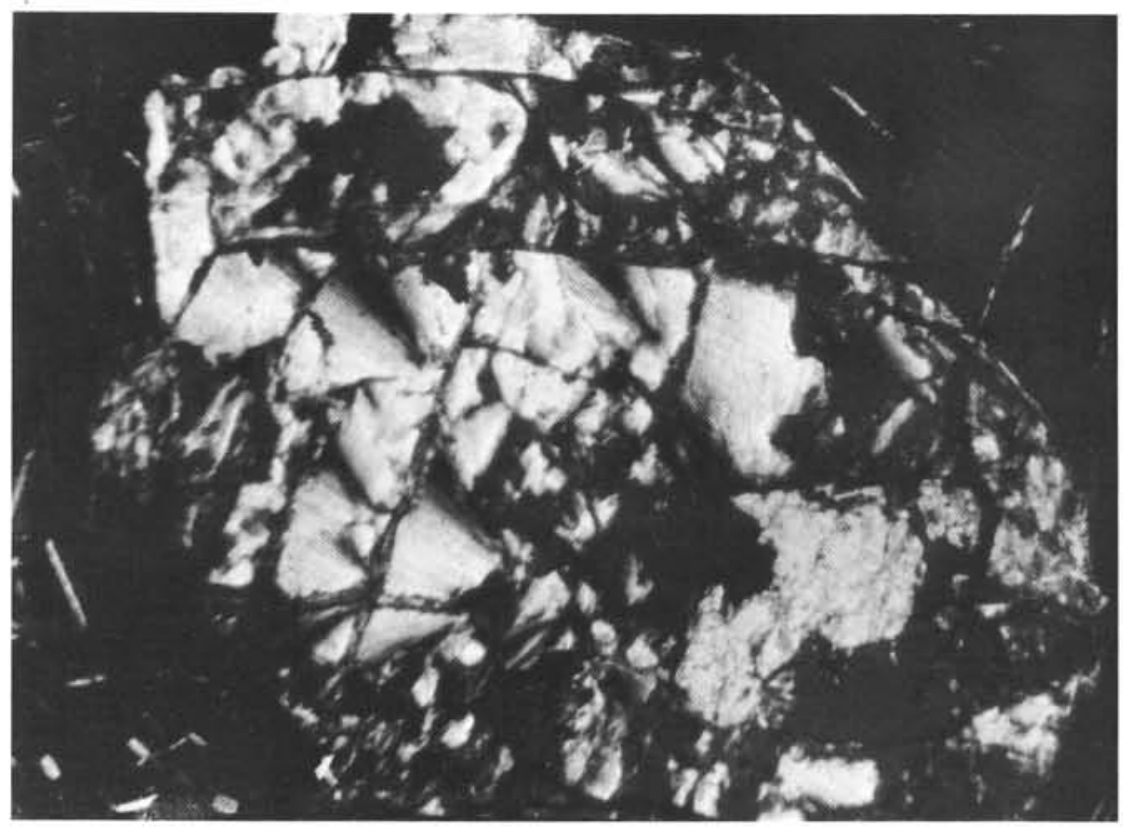

Figure 2. A part of the plagioclase phenocryst replaced by colorless finegrained and spherolitic smectite in basalt. Sample 417A-37-3, $70 \mathrm{~cm}$. Crossed nicols.

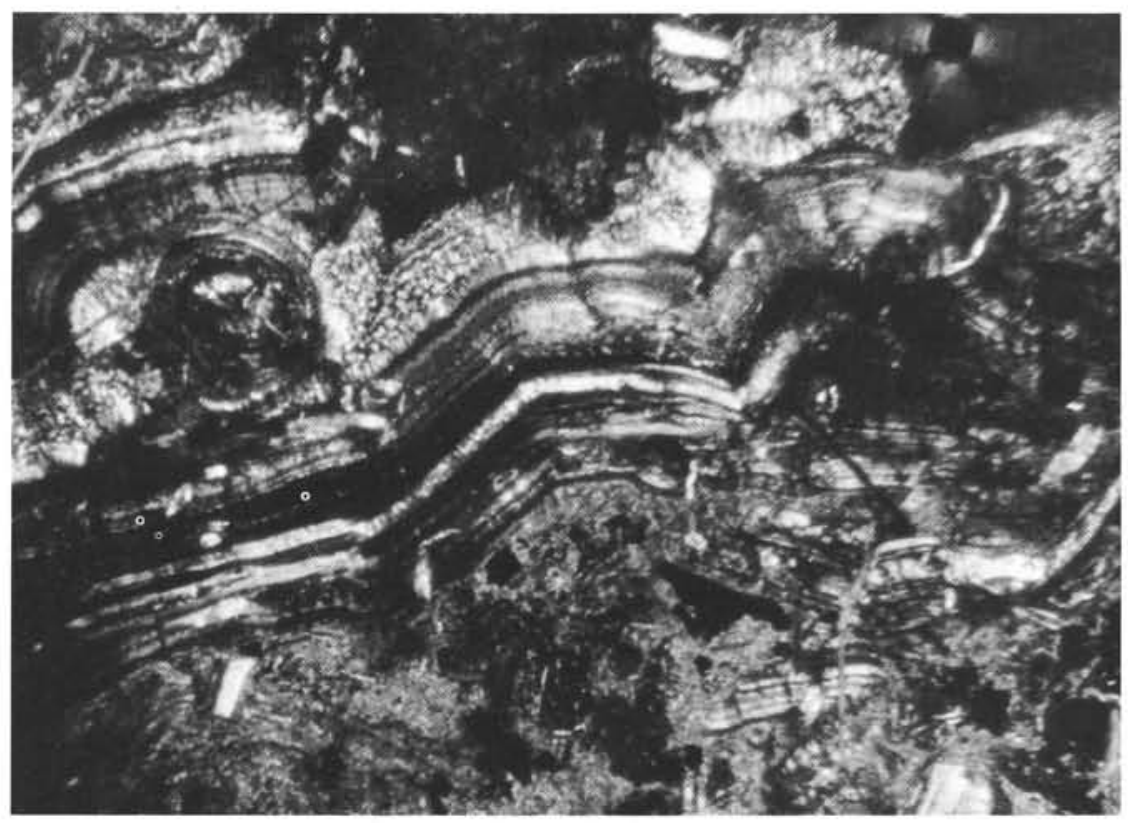

Figure 3. Fine-banded aggregate of green smectite in hyaloclastite. Sample 417-26-2, $58 \mathrm{~cm}$. Crossed nicols.

(Table 1). Measurements were made with a diffractometer DRON-2 with $\mathrm{Fe}$-radiation filtered with $\mathrm{Ni}$; the speed of rotation was $2 \% \mathrm{~min}$.

\section{CLAY MINERALOGY}

According to the parameter $\mathrm{d}_{001}$ (Figures 4 and 5), two groups of smectites were distinguished: (1) montmorillonites and montmorillonite-like minerals $\left(\mathrm{d}_{001}=\right.$ 11.9 to $14.0 \mathrm{~A}$ )and (2) hydromica $\left(\mathrm{d}_{001}=10\right.$ to $\left.10.2 \mathrm{~A}\right)$.
Phases diagnosed optically as palagonite have diffractograms close to those of montmorillonite; however, the peaks are often diffuse due to a high content of amorphous material. In Figure 6, diffractograms of "palagonite" are noted from different zones of altered glass near a smectite veinlet. Some distance from the veinlet, a glass zone is less altered and has a diffuse peak around 13 to $14 \AA$. In thin section, this altered glass is brown, isotropic with low indexes $(n=1.523 \pm 0.003)$, 
TABLE 1

X-Ray Powder Data for Smectites From Hole 417A

\begin{tabular}{|c|c|c|c|c|c|c|c|c|c|c|c|}
\hline \multicolumn{3}{|c|}{1} & \multicolumn{3}{|c|}{2} & \multicolumn{3}{|c|}{3} & \multicolumn{3}{|c|}{4} \\
\hline A & & B & A & & B & A & & B & A & & B \\
\hline d & & d & d & & d & d & & d & d & & d \\
\hline $\mathrm{n}$ & 1 & $\mathrm{n}$ & $\mathrm{n}$ & 1 & n & $\mathrm{n}$ & 1 & $n$ & $\mathrm{n}$ & 1 & $n$ \\
\hline 14.22 & $9 b$ & 17.5 & 11.36 & $10 \mathrm{~b}$ & 17.3 & 13.69 & $10 \mathrm{~b}$ & 17.3 & 14.16 & 10 & 15.8 \\
\hline$=$ & - & 10.3 & $\bar{z}$ & & 10.36 & $\overline{6.15}$ & $\overline{4}$ & - & 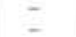 & & $=$ \\
\hline- & & & - & & & 5.59 & 9 & - & & & \\
\hline $\begin{array}{l}4.87 \\
4.45\end{array}$ & $\begin{array}{r}4 \\
10\end{array}$ & & & ${ }_{10}^{4}$ & & 4.82 & 6 & & 4.82 & $4 \mathrm{~b}$ & \\
\hline $\begin{array}{r}4.45 \\
-\end{array}$ & 10 & & 4.45 & 10 & & $\begin{array}{l}4.45 \\
3.81\end{array}$ & ${ }_{7}^{86}$ & & $\begin{array}{l}4.45 \\
3.82\end{array}$ & $\begin{array}{l}1 \\
1\end{array}$ & \\
\hline- & - & & 3.53 & 1 & & 3.68 & 1 & & & - & \\
\hline & - & & 3.34 & 1 & & 3.42 & 10 & & 3.32 & 1 & \\
\hline 3.21 & lb & & - & - & & 3.12 & 2 & & 3.20 & 2 & \\
\hline $\bar{z}$ & - & & $\overline{3.02}$ & $\overline{7}$ & & $\begin{array}{l}3.07 \\
2.925\end{array}$ & $\frac{1}{9}$ & & 3.01 & 2 & \\
\hline 2.83 & $1 \mathrm{~b}$ & & 2.83 & 1 & & 2.79 & $1 \mathrm{~b}$ & & 2.76 & $i$ & \\
\hline 2.56 & $8 \mathrm{~b}$ & & 256 & 9 & & $\begin{array}{r}2.69 \\
252\end{array}$ & 4 & & 2.62 & 4 & \\
\hline 2.38 & 2 & & 2.36 & 1 & & $\begin{array}{l}2.52 \\
2.41\end{array}$ & $\begin{array}{l}4 \\
2\end{array}$ & & $\begin{array}{l}2.50 \\
2.39\end{array}$ & $\begin{array}{l}4 \\
1\end{array}$ & \\
\hline 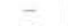 & 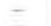 & & - & - & & 2.23 & 3 & & 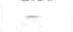 & 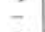 & \\
\hline - & & & 5.92 & $\overline{1}$ & & 2.11 & $\frac{1}{4}$ & & - & - & \\
\hline $\bar{z}$ & - & & 1.88 & 1 & & $\begin{array}{l}1.90 \\
1.87\end{array}$ & $\begin{array}{l}4 \\
3\end{array}$ & & 1.88 & 1 & \\
\hline 1.79 & 1 & & & & & 1.75 & 5 & & 1.79 & 1 & \\
\hline 1.71 & 1b & & 1.71 & 1b & & 1.72 & 1 & & 1.70 & $1 \mathrm{~b}$ & \\
\hline & 16 & & 1.66 & $1 b$ & & 1.69 & 1 & & 1.66 & $1 \mathrm{~b}$ & \\
\hline 1.498 & 7 & & $\begin{array}{l}1.498 \\
1.443\end{array}$ & $8 \mathrm{~b}$ & & 1.498 & 3 & & 1.501 & $6 \mathrm{~b}$ & \\
\hline$\overline{-}$ & - & & 1.442 & 1 & & $\begin{array}{l}\begin{array}{l}1.417 \\
1.355\end{array} \\
\text { a }\end{array}$ & $\begin{array}{l}4 \\
4\end{array}$ & & & E & \\
\hline 1.304 & 1 & & 1.296 & $2 \mathrm{~b}$ & & 1.310 & 2 & & 1.291 & lb & \\
\hline
\end{tabular}

Note: All analyzed smectites were sampled from the cores of Hole 417A: $1=$ Sample $26-4$ $90-92 \mathrm{~cm}$, white clay from pseudomorphs after plagioclase; $2=$ Sample $30-6,91-95 \mathrm{~cm}$, white clay from small vesicles filled with clay and zeolite; $3=S$ smple $34-1,5 \mathrm{~cm}$, white clay from the vein; $4=$ Sample $42-3,108-111 \mathrm{~cm}$, green clay from aitered olivine phenocrysts. $A=$ natural clays; $\mathrm{B}=$ with ethylene-glycol.

and is identified as palagonite. The material is distinctly different from fresh glass, with low indexes and a high water content. Chemical analysis confirms that this "palagonite" is similar to smectite and significantly different from the glass. However, montmorillonitic peaks are diffuse due to the poor crystallinity of smectite during its initial stage of formation.

Electronography data allow recognition in some samples of phases that are highly disordered along the $\mathrm{C}$-axis crystal structure. Sometimes, these crystals are seemingly two-dimensional. Thus, it is possible that the material described as palagonite is an altered glass with a nucleus of layered structure.

Smectites with $d_{001}=12$ to $14 \AA$ swell with ethyleneglycole, up to $\mathrm{d}_{001} \stackrel{001}{=} 16$ to $17 \AA$. In Figure 6 , diffractograms are shown for smectites from a cavity from surrounding basalt which is altered in various degrees, and from a small vesicle. In all patterns, montmorillonites have a similar $\mathrm{d}_{001}$ parameter and degree of swelling, but samples vary in their degree of crystallinity. The highest degree of crystallinity is established for montmorillonite from the cavity and vesicle, with less crystallinity in the metasomatic stage of basaltic glass.

The smectites under investigation also differ in their $\mathrm{d}_{060}$ parameters, depending on the character of octahedral layer fillings. Smectites formed after palagonized glass usually have greater $d_{060}$ (Figure 7; Nos. 1, $2,3,4$, and 6), typical for tri-octahedral minerals. Light colored smectites formed metasomatically after plagioclase and filling vesicles and cracks are close to dioctahedral ones (Figure 7; No. 5; Table 1). In some samples, a mixture of the two types of smectites is recognized and, correspondingly, there are peaks near 1.500 and $1.530 \AA$ on the diffractograms.

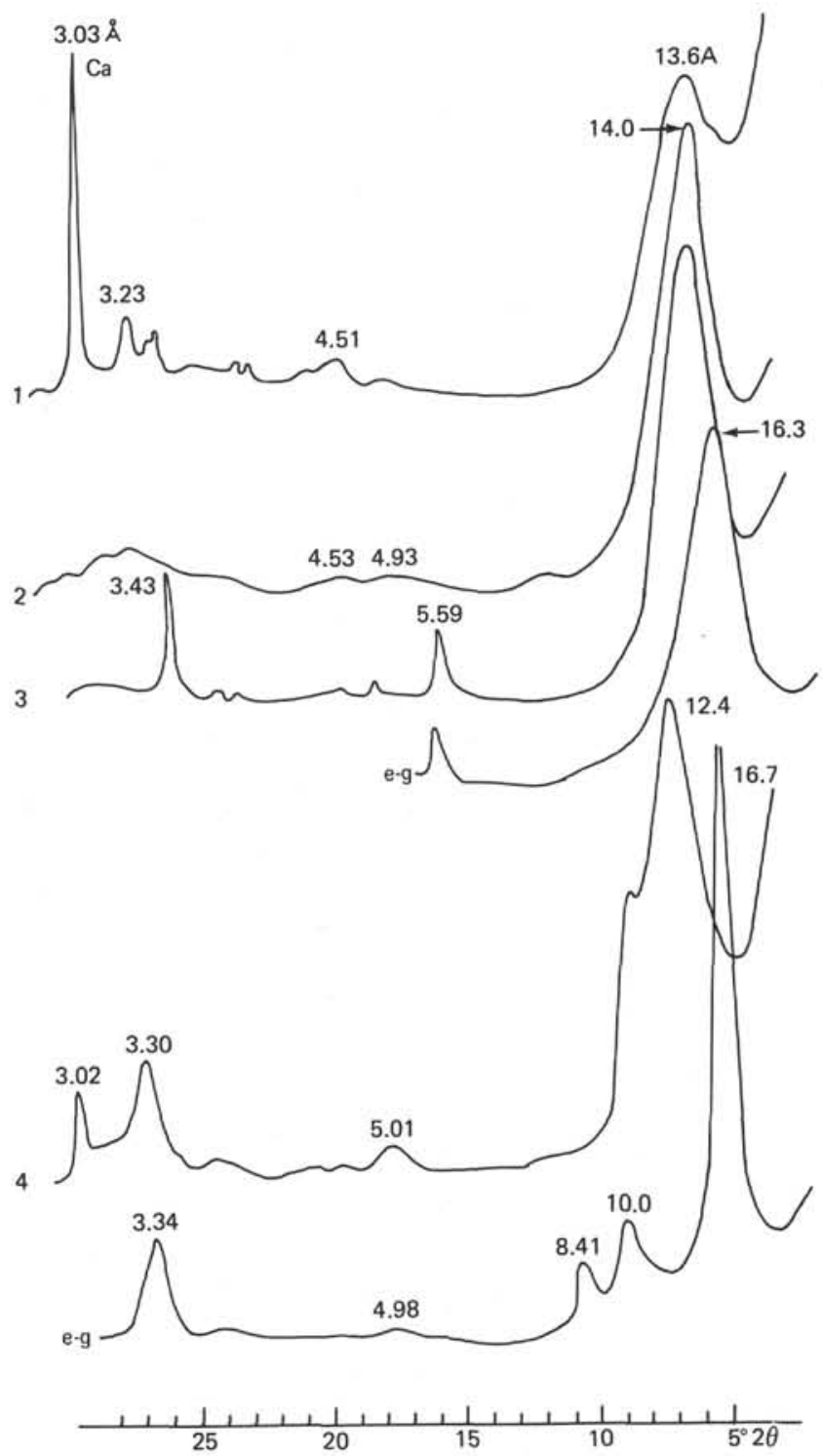

Figure 4. X-ray diffractograms of clay minerals. 1 to $3=$ montmorillonites $(1=$ Sample $417 A-26-1,90$ $\mathrm{cm} ; 2$ = Sample $417 A-26-5,75 \mathrm{~cm} ; 3$ = Sample $417 A-38-2,103 \mathrm{~cm}) ; 4=$ a mixture of montmorillonite with celadonitic hydromica (Samples $417 D-22-1$, $45 \mathrm{~cm}), e-g=$ with ethylene glycole; $\mathrm{Ca}=$ calcite admixture.

Investigations of the chemical composition of smectites (Table 2) were made with a microprobe analyzer MS-46 "Cameca" using corresponding oxides as standards and tension equal to 15 to $20 \mathrm{kv}$. In the process of calculation, some corrections were used for atomic numbers and characteristic fluorescence. Analyzed minerals vary in composition within a single lamella, and analyses show some uncertainties because the data represent an average value of 10 to 20 measurements (which sometimes differ significantly from each other, especially in $\mathrm{SiO}_{2}$ content). Total iron was determined; but ferric and ferrous states were not recognized. 


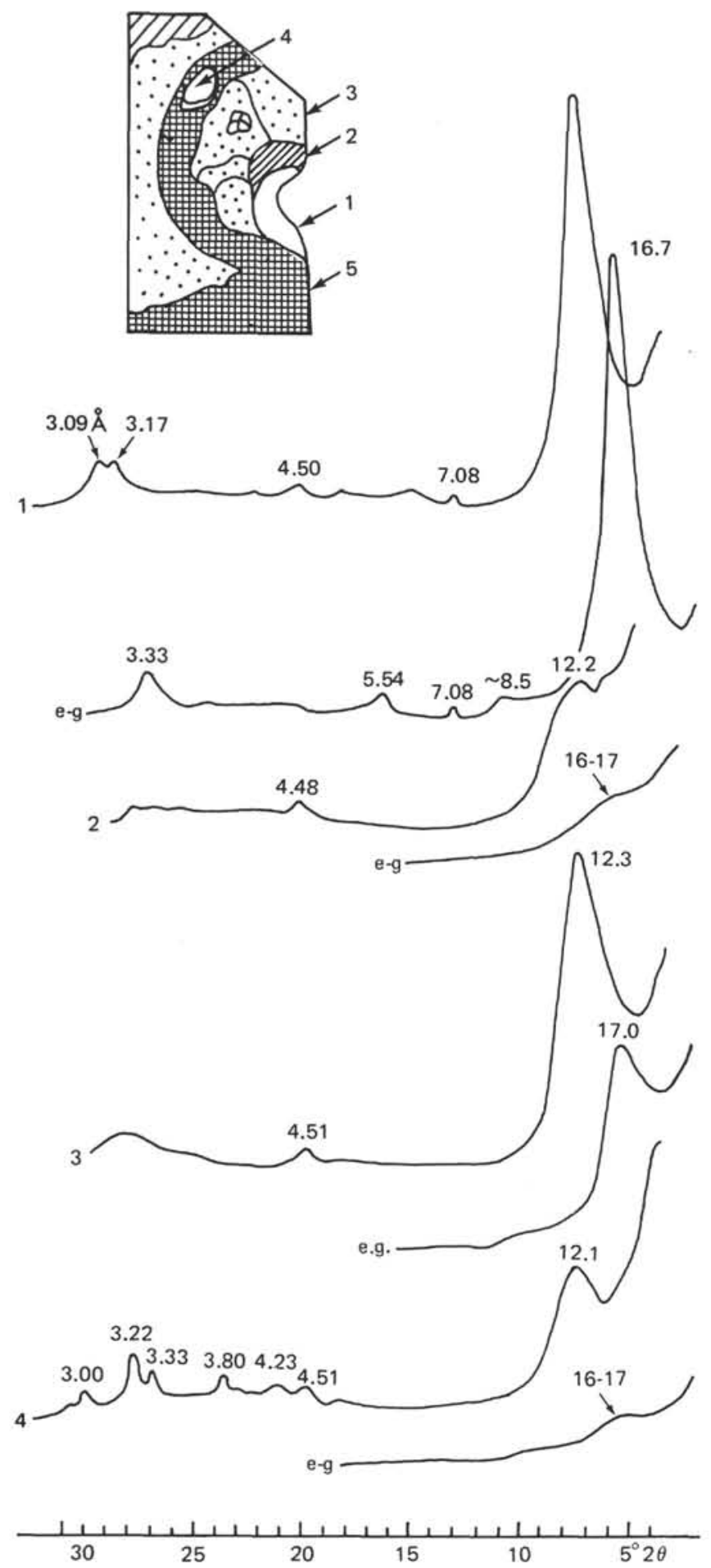

Figure 5. X-ray diffractograms of montmorillonites from Sample $417 A-30-4,122 \mathrm{~cm} .1=$ white smectite in a large cavity; 2 = white smectite in a calcite vesicle; 3 = green smectite replacing glass; $4=$ white smectite in an amygdule; $5=$ brown smectite with iron hydroxides.

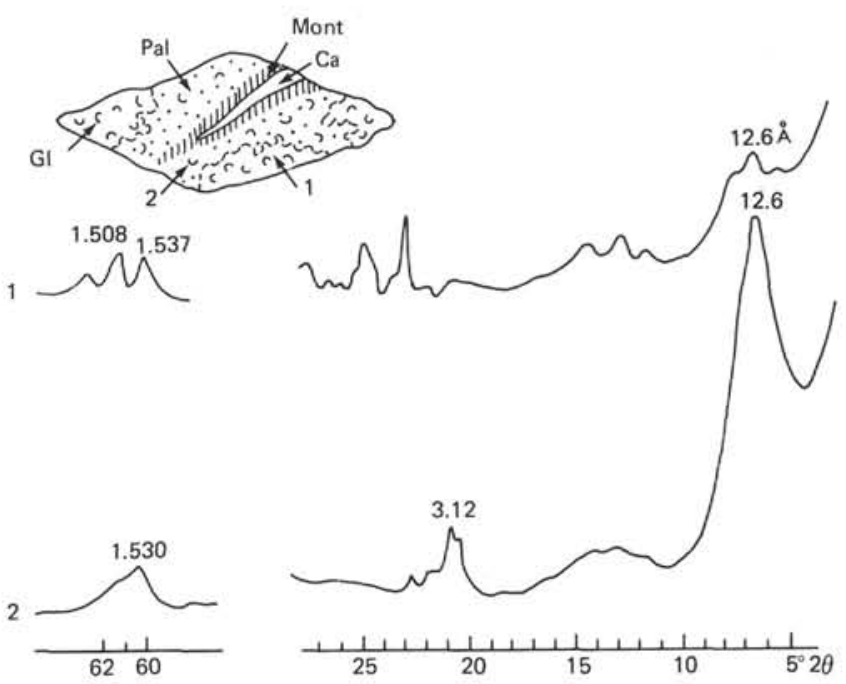

Figure 6. X-ray diffractograms of a palagonite and smectite from Sample 417D-30-5, 67-73 cm. Ca= calcite vein; $M=$ smectite (montmorillonite) rimming the vein; $P a l=$ palagonite; $G l=$ glass; 1 and 2 $=$ sample locations, correspond to numbers of diffractograms.

Recalculation of analyses was conducted, assuming that the total charge of cations in smectites equals 22 . We attempted to differentiate the ferric and ferrous iron using crystal-chemical formulas. In smectites with a high iron content, most octahedral positions are occupied by $\mathrm{Fe}$, and the $\mathrm{Al}$ content is low. In some samples, Fe occupies a part of the tetrahedral positions as well. The probability that $\mathrm{Fe}$ appears as ferric ions (which are isomorphous with $\mathrm{Al}^{3+}$ ) is a question discussed in detail in the description of celadonite.

Therefore, we interpret all $\mathrm{Fe}$ as ferric in iron-rich smectites and ferrous in low-iron ones. In some samples, a high content of $\mathrm{Mg}$ is noted, sometimes having octahedral cations $>2.00$. This may be the result of the following: (1) some $\mathrm{Mg}^{2+}$ cations are in interlayers, and (1) the mineral is more or less trioctahedral. In some cases, the predominance of one cause over the other remains unclear; thus, in Table 2, all $\mathrm{Mg}$ is placed in octahedral positions.

On the basis of chemical data (Table 2), smectites and mixed-layered minerals are divided into three groups corresponding to their optical properties. Colorless and light green minerals have $\mathrm{Al}$ as the main octahedral cation (with admixture of $\mathrm{Mg}$ ) and $\mathrm{Ca}$ in the interlayers. The Si:Al ratio (in terms of atoms per unit cell) varies from 1.49 to 1.97 (3:2 to $4: 2$ ); according to Ross and Hendricks (1945), this corresponds to the range of beidellyite to beidellyite-montmorillonite. The $\mathrm{A} 1^{\mathrm{VI}}$ content is rather high (1.59 to 1.82$), \mathrm{A}^{\mathrm{IV}}$ is 0.29 to 0.52 . A small admixture of $\mathrm{K}^{+}$is observed in the interlayers. The $\mathrm{K}_{2} \mathrm{O}$ content is sometimes as high as 4 per cent and is 

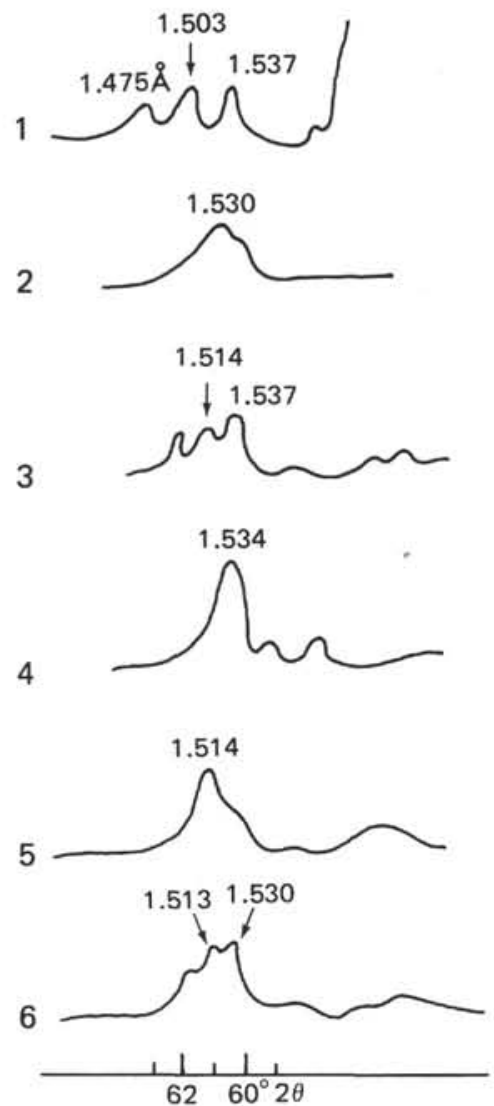

Figure 7. Portions of diffractograms of smectite within the reflection of (060). 1 and $2=417 D-30-5,67-73$ $\mathrm{cm}$ (see Figure 6, corresponding numbers 1 and 2); 3, 4 , and $6=$ green smectite from altered glass $(3=$ Sample 417D-59-3, 101-106 cm; 4 = Sample 417D$68-4,10-12 \mathrm{~cm} ; 6$ = Sample 418A-40-2, $79-84 \mathrm{~cm}$ ); $5=$ white smectite from the vesicle (Sample 418A40-2, 43-48 cm).

caused by the presence of some mica layers in smectites. The $\mathrm{Si}$ content decreases with increasing $\mathrm{K}$, to the approximate level for K-rich micas. Green and light brown smectites are characterized by high $\mathrm{Mg}$ content. $\mathrm{Mg}^{2}+$ is the main cation in interlayers and is embedded in octahedral positions. $\mathrm{Al}$ is low, with $\mathrm{A} 1^{\mathrm{VI}}$ varying from 0.21 to 1.00 , and $\mathrm{A} 1^{\mathrm{IV}}$ varying from 0.20 to 0.48 . Octahedral positions are also rich in iron, but tetrahedral positions are very rich in $\mathrm{Si}$; thus, the $\mathrm{Si}: \mathrm{Al}$ ratio ranges from 2.8 to 7.1, corresponding to montmorillonite.

The minerals belong to a nontronite-montmorillonite series because of their high content of $\mathrm{Fe}$. Additionally, they have a type of octahedral layer intermediate between di- and trioctahedral layers, i.e., they are intermediate phases between the nontronite-montmorillonite and saponite series.

Brown smectites are distinctly different, having extremely high $\mathrm{Fe}$ content. Iron enters not only octahedra, but also the tetrahedra, to compensate for insufficient contents of $\mathrm{Al} . \mathrm{Mg}^{2+}$ dominates in the interlayers; smectites of this type are similar to nontronite or saponite. The $\mathrm{Si}: \mathrm{Al}$ ratio is very high (6.70 to 11.45$)$ because of the low $\mathrm{Al}$ content: $\mathrm{A} 1^{\mathrm{VI}}=0$ to 0.11 atoms/unit cell, $\mathrm{Al}^{\mathrm{IV}}=0.22$ to 0.57 atoms/unit cell. However, in one sample (418A-85-1, 32-34 cm) no Al was detected.

Among minerals formerly described as smectites (Table 2), there are numerous phases that belong to mixed-layered silicates. Some contain rather high $\mathrm{K}_{2} \mathrm{O}$ (see Table 2). Sample 418A-59-5, 58-61 cm is very close to celadonite, but contains too much $\mathrm{CaO}$ in its interlayers.

Titanium is low in most of the analyzed smectites, but is rather high (up to 5.86 wt. $\% \mathrm{TiO}_{2}$ ) in four samples, two of which also contained $\mathrm{V}_{2} \mathrm{O}_{5}(0.13$ and 0.24 wt. $\%$ ).

Celadonite contains excess water and can be termed "hydroceladonite" with transitions to mica-montmorillonite. Celadonite, while observed in all the investigated holes is less abundant than smectites. Celadonite decreases downhole until it disappears near the bottom of Holes 417A and 417D. Detailed investigations of celadonite are difficult because of its common association with smectite; it is impossible to separate these minerals from each other. In the diffractogram (Figure 4), peaks of celadonite and smectite are not clearly distinguishable from those of amorphous material. Celadonite replaces olivine (often with green smectite or calcite), plagioclase phenocrysts (with colorless smectite, K-feldspar, or zeolites), and basaltic glass (with calcite and brown smectite). It also rims some amygdules, filled with green or brown smectite, calcite, and iron hydroxides. In some veinlets of analcime + celadonite, the celadonite forms finegrained aggregates which are bright green with strong pleochroism $(\gamma=$ bright green, $\alpha=$ light greenish yellow) and has $\gamma=1.580$ to 1.596 , and $\gamma=1.603$ to 1.625. In thin sections, the birefringence seem low because lamellae are quite small. Electronographic study reveals that the mica under investigation is a single-layer polytype IM with a varying degree of crystallinity. Celadonites differ from smectites with high $\mathrm{K}$ and low $\mathrm{Ca}$ in the interlayers. However, these values vary significantly and there is a gradual transition between these mineral series. The absence of discontinuity is caused by formation of the range of mixedlayered phases (mica-montmorillonite type). That all the celadonites are hydromica is confirmed by the relatively low sum of oxides in analysis (Table 3), which means a high content of water. We conditionally place the boundary between celadonite and smectite at 4 per cent $\mathrm{K}_{2} \mathrm{O}$ (mineral with $\mathrm{K}_{2} \mathrm{O}<4 \%=$ smectite). Calculations of the composition per unit cell are made assuming that the total charge of cations equals 22 . All Fe is calculated as ferric iron, but it is possible (with calculated formulas) to estimate approximately the real value for the ratio of $\mathrm{Fe}^{3+}:\left(\mathrm{Fe}^{3+}+\mathrm{Fe}^{2+}\right)$. In $\mathrm{Mg}$-rich dioctahedral micas, the $\mathrm{Al}$ content is as low as 1.5 atoms; but, in analyzed celadonites, only 0.0 to 0.28 atoms/unit cell $\mathrm{Al}$ occur. Assuming that $\mathrm{Al}$ is replaced by $\mathrm{Fe}^{3+}$, we may conclude that $\mathrm{Fe}^{2+}=\left(\mathrm{Al}+\mathrm{Fe}_{\text {total }}\right)=1.5$. According to analyses presented in Table 3 , this value equals 0.0 to 0.16 atoms/unit cell; the degree of iron oxidation is as high as $\mathrm{Fe}^{3+}: \mathrm{Fe}_{\text {total }}=0.88$ to 1.0 . This high value is confirm- 
TABLE 2

Microprobe Analyses of Smectite

\begin{tabular}{|c|c|c|c|c|c|c|c|c|c|c|c|c|c|c|c|c|c|}
\hline Oxides & 1 & 2 & 3 & 4 & 5 & 6 & 7 & 8 & 9 & 10 & 11 & 12 & 13 & 14 & 15 & 16 & 17 \\
\hline $\mathrm{SiO}_{2}$ & 55.8 & 53.28 & 54.20 & 56.5 & 49.13 & 50.8 & 50.9 & 43.49 & 31.39 & 51.63 & 49.66 & 39.02 & 29.7 & 45.02 & 42.16 & 45.44 & 52.51 \\
\hline $\mathrm{TiO}_{2}$ & 0.0 & 0.0 & 0.0 & 0.28 & 5.86 & 0.0 & 0.0 & 0.88 & 2.25 & 0.06 & 0.09 & 0.0 & 0.05 & 4.6 & 0.41 & 0.02 & 0.0 \\
\hline $\mathrm{Al}_{2} \mathrm{O}_{3}$ & 32.0 & 26.30 & 23.51 & 15.2 & 14.76 & 6.0 & 6.7 & 4.93 & 3.99 & 4.27 & 3.73 & 5.57 & 3.73 & 5.53 & 6.13 & 6.36 & 0.03 \\
\hline $\mathrm{FeO}$ & 1.3 & 3.02 & 4.34 & - & 8.28 & 15.7 & 12.9 & - & - & - & - & - & - & - & - & - & - \\
\hline $\mathrm{Fe}_{2} \mathrm{O}_{3}$ & - & - & - & 15.94 & - & - & - & 27.62 & 35.99 & 13.06 & 15.41 & 28.70 & 39.50 & 19.08 & 7.92 & 17.81 & 10.18 \\
\hline $\mathrm{MnO}$ & 0.08 & 0.06 & 0.0 & 0.0 & 0.03 & 0.0 & 0.0 & 0.01 & 0.08 & 0.04 & 0.04 & 0.0 & 0.03 & 0.0 & 0.0 & 0.0 & 0.01 \\
\hline $\mathrm{MgO}$ & 3.9 & 5.38 & 3.54 & 3.3 & 3.24 & 15.7 & 18.3 & 10.64 & 9.59 & 20.6 & 15.67 & 10.32 & 6.12 & 11.15 & 14.8 & 16.14 & 24.64 \\
\hline $\mathrm{CaO}$ & 0.47 & 0.48 & 0.50 & 1.0 & 4.04 & 1.5 & 1.8 & 1.80 & 2.22 & 0.82 & 0.82 & 1.24 & 0.95 & 1.38 & 2.14 & 1,93 & 0.55 \\
\hline $\mathrm{Na}_{2} \mathrm{O}$ & 0.35 & 0.08 & 0.09 & 0.0 & 3.6 & 0.0 & 0.0 & 0.0 & 0.03 & 0.10 & 0.09 & 0.05 & 0.0 & 0.23 & 0.09 & 0.0 & 0.06 \\
\hline $\mathrm{K}_{2} \mathrm{O}$ & 0.95 & 0.59 & 1.77 & 0.28 & 1.20 & 0.0 & 0.0 & 2.36 & 0.79 & 0.14 & 0.13 & 1.60 & 3.30 & 4.6 & 0.08 & 0.07 & 0.12 \\
\hline $\mathrm{V}_{2} \mathrm{O}_{5}$ & - & - & - & - & - & - & - & 0.13 & 0.24 & - & - & - & - & - & - & - & - \\
\hline Total & 94.85 & 89.19 & 87.96 & 95.28 & 90.14 & 89.7 & 90.6 & 90.75 & 85.13 & 90.2 & 85.15 & 85.35 & 81.8 & 86.23 & 83.01 & 87.06 & 87.7 \\
\hline $\mathrm{Si}$ & 9.48 & 3.56 & 3.71 & 3.80 & 3.52 & 3.72 & 3.64 & 3.45 & 2.88 & 3.71 & 3.78 & 3.11 & 2.97 & 3.31 & 3.30 & 3.37 & 3.75 \\
\hline Al & 0.52 & 0.44 & 0.29 & 0.20 & 0.48 & 0.28 & 0.36 & 0.46 & 0.43 & 0.29 & 0.22 & 0.52 & 0.44 & 0.48 & 0.57 & 0.56 & - \\
\hline $\mathrm{Fe}$ & - & - & - & - & - & - & - & 0.09 & 0.69 & - & - & 0.37 & 0.59 & 0.21 & 0.13 & 0.07 & 0.25 \\
\hline Al & 1.82 & 1.63 & 1.59 & 1.00 & 0.76 & 0.24 & 0.21 & - & - & 0.07 & 0.11 & - & - & - & - & - & - \\
\hline $\mathrm{Fe}$ & 0.07 & 0.17 & 0.25 & 0.81 & 0.49 & 0.96 & 0.77 & 1.67 & 1.95 & 0.75 & 0.88 & 1.35 & 2.58 & 0.85 & 0.92 & 0.92 & 0.30 \\
\hline $\mathrm{Mg}$ & 0.36 & 0.54 & 0.36 & 0.33 & 0.34 & 0.71 & 1.95 & 1.26 & 1.31 & 2.20 & 1.77 & 1.23 & 0.91 & 1.22 & 1.72 & 1.78 & 2.62 \\
\hline $\mathrm{Mn}$ & - & - & - & - & - & - & - & - & 0.01 & - & - & - & - & - & - & - & - \\
\hline $\mathrm{Ti}$ & - & - & - & 0.02 & 0.32 & - & - & 0.05 & 0.16 & - & - & - & - & 0.26 & 0.02 & - & - \\
\hline $\mathrm{Ca}$ & 0.03 & 0.04 & 0.04 & 0.08 & 0.31 & 0.12 & 0.14 & 0.15 & 0.43 & 0.06 & 0.06 & 0.11 & 0.10 & 0.11 & 0.18 & 0.15 & 0.04 \\
\hline $\mathrm{Na}$ & 0.04 & 0.01 & 0.02 & 0.0 & 0.50 & - & - & - & 0.01 & 0.02 & 0.02 & 0.01 & - & 0.04 & 0.02 & - & 0.01 \\
\hline K & 0.08 & 0.05 & 0.15 & 0.02 & 0.11 & - & - & 0.23 & 0.10 & 0.01 & 0.01 & 0.17 & 0.42 & 0.43 & 0.01 & - & 0.01 \\
\hline V & - & - & - & - & - & - & - & - & 0.02 & - & - & - & - & - & - & - & - \\
\hline
\end{tabular}

Note: 1 to $3=$ montmorillonite-beidellyite $(1=$ Sample $417 \mathrm{~A}-24-2,81-84 \mathrm{~cm}$. colorless smectite from a vesicle associated with calcite and zeolite; $2=$ Sample $417 \mathrm{~A}-30-6,9 \mathrm{~cm}$, pale green smectite from a plagioclase phenocryst; $3=$ the same sample as No. 2 , colorless smectite from a veinlet); $4=$ Sample $417 \mathrm{D}-30-4,25-27 \mathrm{~cm}$, green beidellyite-nontronite from a vesicle; 5 = Sample 417D-48-6, 85-87 cm, from a phenocryst of olivine(?); 6 = Sample 417D-52-4, 13 cm, from a vesicle; $7=$ Sample 417D-59-3, 101-106 cm, from an olivine phenocryst: 8 to $11=$ nontronite from Hole 417D ( 8 and $9=$ Sample $417 \mathrm{D}-60-2,128-130 \mathrm{~cm}$, intense yellow smectite from a vesicle associated with celadonite and Fehydroxides; 10 and $11=417 \mathrm{D}-69-1,141-143 \mathrm{~cm}$, dark brown and light brown, respectively, from altered glass in a groundmass of basalt); 12 to $17=$ nontronite from Hole $417 \mathrm{~A}$ (12 to $14=$ Sample $418 \mathrm{~A}-69-5,58-61 \mathrm{~cm}$, bright brown, in the case of 12 and 13 , and intensely green, e.g., 14 , from a marginal part of the pillow; 15 and $16=$ Sample $418 \mathrm{~A}-$ $79-1,112-114 \mathrm{~cm}$, brownish green smectite from a vesicle filled with calcite; $17=$ Sample $418 \mathrm{~A}-85-1,32-34 \mathrm{~cm}$, brown smectite from glass in basaltic groundmass).

TABLE 3

Microprobe Analyses of Celadonite

\begin{tabular}{lrrrrrrrrrrr}
\hline Oxides & 1 & 2 & 3 & 4 & 5 & 6 & 7 & 8 & 9 & 10 & 11 \\
\hline $\mathrm{SiO}_{2}$ & 51.02 & 50.68 & 50.56 & 35.8 & 46.5 & 53.3 & 49.06 & 51.7 & 50.37 & 46.56 & 53.8 \\
$\mathrm{TiO}_{2}$ & 0.11 & 0.02 & 0.04 & 0.5 & 0.00 & 0.0 & 0.04 & 0.0 & 0.02 & 0.15 & 0.0 \\
$\mathrm{Al}_{2} \mathrm{O}_{3}$ & 5.31 & 8.13 & 3.92 & 5.1 & 3.6 & 2.6 & 3.59 & 3.91 & 5.18 & 5.53 & 1.8 \\
$\mathrm{Fe}_{2} \mathrm{O}_{3}$ & 27.02 & 25.63 & 25.00 & 33.86 & 28.44 & 23.34 & 25.69 & 26.17 & 24.74 & 24.11 & 27.92 \\
$\mathrm{MnO}$ & 0.04 & 0.01 & 0.0 & 0.0 & 0.0 & 0.0 & 0.01 & 0.0 & 0.01 & 0.03 & 0.0 \\
$\mathrm{MgO}$ & 4.43 & 3.72 & 3.95 & 7.3 & 6.2 & 5.1 & 5.06 & 5.14 & 5.59 & 5.55 & 3.9 \\
$\mathrm{CaO}$ & 0.43 & 0.35 & 0.38 & 0.6 & 0.6 & 0.45 & 1.22 & 0.99 & 1.62 & 1.65 & 0.4 \\
$\mathrm{Na} 2 \mathrm{O}$ & 0.29 & 0.01 & 0.14 & 0.0 & 0.0 & 0.0 & 0.0 & 0.0 & 0.05 & 0.14 & 0.0 \\
$\mathrm{~K}_{2} \mathrm{O}$ & 6.80 & 6.40 & 6.1 & 4.0 & 6.3 & 7.4 & 5.82 & 6.09 & 4.09 & 4.84 & 3 \\
$\mathrm{~V} 2 \mathrm{O}_{5}$ & & & & & & & & & 0.02 & 0.02 & \\
$\mathrm{Total}$ & 95.44 & 94.95 & 89.09 & 85.8 & 90.5 & 91.25 & 89.46 & 92.96 & 90.71 & 87.62 & 90.82 \\
$\mathrm{Si}$ & 3.64 & 3.60 & 3.70 & 2.94 & 3.51 & 3.90 & 3.69 & 3.73 & 3.68 & 3.63 & 3.93 \\
$\mathrm{Al}$ & 0.36 & 0.40 & 0.30 & 0.49 & 0.32 & 0.10 & 0.31 & 0.27 & 0.32 & 0.37 & 0.07 \\
$\mathrm{Fe}$ & - & - & - & 0.57 & 0.17 & - & - & - & - & - & - \\
$\mathrm{Al}$ & 0.09 & 0.28 & 0.04 & - & - & 0.12 & 0.01 & 0.06 & 0.13 & 0.14 & 0.09 \\
$\mathrm{Fe}$ & 1.47 & 1.38 & 1.32 & 1.53 & 1.46 & 1.29 & 1.46 & 1.42 & 1.36 & 1.43 & 1.53 \\
$\mathrm{Mn}$ & - & - & - & - & - & - & - & - & - & - & - \\
$\mathrm{Mg}$ & 0.47 & 0.39 & 0.78 & 0.89 & 0.70 & 0.56 & 0.57 & 0.55 & 0.61 & 0.65 & 0.42 \\
$\mathrm{Ti}$ & - & - & - & 0.12 & - & - & - & - & - & 0.01 & - \\
$\mathrm{Ca}$ & 0.03 & 0.03 & 0.03 & 0.05 & 0.05 & 0.03 & 0.09 & 0.08 & 0.13 & 0.14 & 0.03 \\
$\mathrm{Na}$ & 0.04 & - & 0.02 & - & - & - & - & - & 0.01 & 0.02 & - \\
$\mathrm{K}$ & 0.62 & 0.58 & 0.58 & 0.41 & 0.61 & 0.69 & 0.56 & 0.56 & 0.38 & 0.48 & 0.28 \\
\hline
\end{tabular}

Note: 1 and 2 = Sample $417 \mathrm{~A}-30-6,9 \mathrm{~cm}(1=$ bright green from a vesicle $; 2$ green from a plagioclase phenocryst associated with pale green smectite, see Table 2, No. 2$) ; 3$ to $11=$ Hole $417 \mathrm{D}$ samples ( 3 = Sample 48-6, 85-87 cm, green from a vesicle; 4 to $6=$ Sample $49-2,81-83 \mathrm{~cm}$, from the altered glass in groundmass of basalts; 4 and 6 are green bands intercalated with colorless represented by 5); 7 to $10=$ Sample $60-2,128 \mathrm{~cm}(7$ and $8=$ yellowish green mica from a vesicle, where $7=$ margin, $8=$ inner part; $9=$ reddish brown mica after glass in a marginal part of the pillow; 10 = deep yellow micaceous substance replacing glass and intercalated with the reddish brown substance of No. $9 ; 11=$ Sample $52-4,13 \mathrm{~cm}$, green mica from an olivine phenocryst). 
ed by the high degree of iron oxidation in the rocks under study (see Table 2). Therefore, we may conclude that investigated hydromicas are very rich in the ferric iron that occupies not only octahedral positions, but sometime tetrahedral ones. The value of the $\mathrm{Fe}^{2+}:(\mathrm{Mg}+$ $\mathrm{Fe}^{2+}$ ) ratio is very low ( 0 to 0.3$)$. The $\mathrm{Mg}$ content is high, thus explaining why the value of octahedral cations in formulas is $>2.0$. In some cases, a portion of the $\mathrm{Mg}$ enters swelling interlayers, but this is obviously not the only cause; at least part of the $\mathrm{Mg}$ caused a surplus of octahedral cations.

Among cations in interlayers (except $\mathrm{K}$ ), $\mathrm{Ca}$ is always present, with $\mathrm{Na}$ being less abundant. In the samples under study, vanadium (V) was checked. Because these samples are characterized by high $\mathrm{Ca}$ and may be mixedlayer phases, $\mathrm{V}$ may be fixed in the interlayers. This is plausible because some of the smectite are V-rich. Our analyses of celadonites and smectites coincide with data of J. R. Cann (personal communication) for "protoceladonite" $\left(\mathrm{SiO}_{2}=50, \mathrm{Al}_{2} \mathrm{O}_{3}=1.5, \mathrm{FeO}=26\right.$ with total iron calculated as $\mathrm{FeO}, \mathrm{MgO}=5, \mathrm{CaO}=0.7$, and $\mathrm{K}_{2} \mathrm{O}=7$ wt. \%) and "saponite" $\left(\mathrm{SiO}_{2}=44, \mathrm{Al}_{2} \mathrm{O}_{3}=\right.$ $6, \mathrm{FeO}=11, \mathrm{MgO}=17, \mathrm{CaO}=1, \mathrm{Na}_{2} \mathrm{O}=0.5$, and $\mathrm{K}_{2} \mathrm{O}=0.5$ ). Palagonites investigated in basalts from Holes 417A, 417D, and 418A are intermediate products of smectites replacing basaltic glass. Palagonite is a brown isotropic material with low refractive indexes. Chemically, it is not homogeneous, varying within the same thin section in $\mathrm{MgO}, \mathrm{Al}_{2} \mathrm{O}_{3}$, and $\mathrm{SiO}_{2}$ content (Table 4, Nos. 3, 4). Palagonites differ distinctly from the glass with extremely low $\mathrm{CaO}$, lower $\mathrm{Na}_{2} \mathrm{O}$, high $\mathrm{H}_{2} \mathrm{O}$, some higher $\mathrm{Al}_{2} \mathrm{O}_{3}$, and commonly high $\mathrm{MgO}$ and total Fe (Table 4, Nos. 5-8). Such strong alteration results in a structural reorganization of the glass; thus, $\mathrm{X}$-ray diffractograms sometimes show only signs of layered silicates. Electronographic analyses indicate the
TABLE 4

Chemical Analyses of Palagonites and Glass

\begin{tabular}{|c|c|c|c|c|c|c|c|c|}
\hline Oxides & 1 & 2 & 3 & 4 & 5 & 6 & 7 & 8 \\
\hline $\mathrm{SiO}_{2}$ & 51.84 & 46.5 & 53.0 & 52.0 & 50.76 & 45.08 & 45.99 & 46.76 \\
\hline $\mathrm{TiO}_{2}$ & 0.96 & 1.6 & 1.9 & 1.9 & 0.32 & 0.0 & 0.0 & 0.0 \\
\hline $\mathrm{Al}_{2} \mathrm{O}_{3}$ & 13.31 & 13.7 & 14.2 & 15.0 & 8.12 & 5.78 & 6.05 & 5.75 \\
\hline $\mathrm{FeO}$ & 11.12 & 10.9 & 12.0 & 11.9 & 17.78 & 15.96 & 15.35 & 15.66 \\
\hline $\mathrm{MnO}$ & 0.17 & 0.16 & 0.0 & 0.0 & 0.0 & 0.0 & 0.03 & 0.0 \\
\hline $\mathrm{CaO}$ & 10.55 & 12.3 & 2.4 & 2.5 & 2.18 & 1.36 & 1.31 & 1.06 \\
\hline $\mathrm{Na}_{2} \mathrm{O}$ & 2.05 & 2.4 & 0.0 & 0.0 & 0.02 & 0.07 & 0.11 & 0.14 \\
\hline $\mathrm{K}_{2} \mathrm{O}$ & 0.29 & 0.07 & 0.53 & 0.54 & 2.94 & 0.04 & 0.07 & 0.07 \\
\hline $\mathrm{V}_{2} \mathrm{O}_{5}$ & 0.0 & 0.0 & 0.0 & 0.0 & 0.04 & 0.0 & 0.0 & 0.0 \\
\hline Total & 100.99 & 94.03 & 89.39 & 88.94 & 91.5 & 85.00 & 86.18 & 87.06 \\
\hline
\end{tabular}

presence of crystal nuclei that are unordered along the $\mathrm{C}$-axis layer structure. The next stage of alteration is growth of smectite crystals and an ordering of their structure. Chemically, a loss of $\mathrm{CaO}$ and $\mathrm{TiO}_{2}$, and a gain of total $\mathrm{Fe}, \mathrm{MgO}$, and (sometimes) $\mathrm{K}_{2} \mathrm{O}$ takes place (compare Tables 2 and 4). At this stage, smectites of different types are formed, i.e., rich in $\mathrm{Fe}$ or $\mathrm{Mg}$. Therefore, palagonite is clearly not a stable mineral phase in the process of basalt alteration, but is a metastable intermediate product formed at the initial stage of smectite formation.

\section{ACKNOWLEDGMENTS}

For reviewing this paper, the authors wish to thank V. I. Finko and other members of the Institute of Ore Deposits, Geology, Petrography, Mineralogy, and Geochemistry; Academy of Sciences, Moscow, USSR.

\section{REFERENCE}

Ross, C. S. and Hendricks, S. B., 1945. Minerals of the montmorillonite group, U. S. Geological Survey Professional Paper 205-B. 